with wide vision have, years ago, foretold the inevitable waste and ruin which would result if the population were allowed to carry on certain practices, including the almost unrestricted pasturage of flocks, more especially goats. The Governments of the day turned a deaf ear. To-day the position has to be faced. Apart from the loss of valuable agricultural land resulting from serious erosion in the hills, part of the water supplies upon which the great network of canals in the Punjab plains depend will be jeopardized unless the extending erosion in the outer hills can be stayed. In several regions of the British Empire this problem of erosion on the large scale and the man-made desert are probably two of the most complicated and most important of the administrative and economic matters facing several Governments.

\section{Education of Young Children}

"Young Children IN European Countries" is the title of a report recently issued (Washington, D.C. : Superintendent of Documents. Pp. 108. 15 cents) by the United States Office of Education. Among the sequelce of the economic depression in that country none aroused greater concern than the physical and mental handicaps imposed upon young children, and emergency nursery schools were established in 1933-35 in nearly all the States; mostly in already existing school buildings but also in hospitals, camps, mines, mills, etc. As these schools proved their value, it became generally recognized that they had come to stay, and it was determined to ascertain what other countries were doing in this field. The senior specialist in nursery-kindergartenprimary education of the Office of Education was, accordingly, sent on a mission of inquiry to England, Scotland, Belgium, Holland, Italy, Austria, Hungary, Czechoslovakia, the Soviet Union and Poland. Hence the present report, which describes administrative and financial arrangements, housing and equipment and the training of nursery school teachers. In addition, the report deals with health and nutrition and family housing in relation to young children. In scientific planning for the staffing of nursery schools, the Soviet Union is pre-eminent with a network of institutes preparing the teachers who are to take care of the $3 \frac{1}{2}$ million children between three and seven years of age for whom nursery and infant schools are to be ready this year. Statistics of attendance in such schools in fourteen countries for 1934 show a maximum of 66 per cent of the population (ages 3-6) in Belgium. France comes next with 52 per cent.

\section{Statistics concerning Non-manual Workers}

THe Advisory Committee on Salaried Employees, set up by the International Labour Office at its meeting on November 18-19, reviewed statistics, compiled by the International Labour Office, relating to non-manual workers in different countries, which show the tendencies for the proportion of salaried employees to workers to rise in recent years, to which attention was recently directed at the British Association meeting by Mr. S. W. Stephen.
The proportion of women among salaried workers has also risen markedly since before the Great War. In industrial countries, non-manual workers now represent $20-30$ per cent of the occupied population. In noting the general tendencies, the Committee recommends that the International Labour Office should continue its studies in this field. Attention was also given to the question of notice of termination of contracts, and opinion was expressed that formal rules should be introduced in this respect in countries where they are not yet in existence. Such regulations should provide for a minimum period of notice to be given by the employer in accordance with the importance of the work performed or its remuneration. A report on the effects of the use of office machinery on conditions of work for staff was also considered, and measures for improving the standing of office employees and protecting them against some of the effects of mechanization were suggested. These suggestions cover essentially the type of work at present being carried out by the National Institute of Industrial Psychology, so far as its resources permit. The protection of the health of employees was also considered, attention being directed to the unsatisfactory conditions in many shops and offices, including warehouses and the premises of forwarding agents, from the point of view of the health, comfort and safety of the staff.

\section{South African Herbage Crops}

THe grasslands and forage crops of the British Dominions and Colonies have been the subject of various issues in the Herbage Publication Series, New Zealand and Australia being dealt with in Bulletins 11 and 14 respectively, while papers on research in India and Canada have appeared in Herbage Reviews. The most recent addition to this series published by the Herbage Bureau, Aberystwyth, is Bulletin 18 entitled, "Pastures and Forage Crops in South Africa" (Aberystwyth : Imperial Bureau of Plant Genetics. $3 s$.) in which contributions are made by such recog. nized authorities as I. B. Pole Evans, A. R. Saunders, J. W. Rowland and S. R. de Villiers. The four distinct types of natural pasture, namely, parkland, grassland, desert shrub and sclerophyllous bush are described in detail so that the special problems associated with each of them are clearly indicated. The discovery that the general decline in carrying capacity of the veld had resulted from faulty grazing management has led to a research programme being developed on national lines to enable the natural pastoral resources to be more efficiently utilized. At the same time, the progressive nature of the livestock policy has brought the question of fodder crops to the fore, and more attention will have to be paid to the production of legumes in the future. The importance of breeding work is also recognized, and as a result of the intensive botanical survey recently undertaken, a large and valuable collection of indigenous grasses has been made. From this it is hoped to build up the types of herbage most suitable for the various districts, introduction of grasses from Europe or America being largely ruled out owing to the differences in climatic conditions. 